Effects of Kaolin Particle Film Treatment on Table Grape Characteristics of cv. Trakya Ilkeren ( $V$. vinifera L.)

\author{
Sevil CANTÜRK ${ }^{1}$, Birhan KUNTER2 ${ }^{2}$ \\ ${ }^{1}$ Department of Horticulture, Faculty of Agriculture, Çukurova University, Sarıçam, Adana, Turkey, ${ }^{2}$ Department of Horticulture, Faculty of \\ Agriculture, Ankara University, Diskapi, Ankara, Turkey \\ ${ }^{1}$ https://orcid.org/0000-0001-6055-7191, ${ }^{2}$ https://orcid.org/0000-0001-7112-1908 \\ $\bowtie$ : marasali@agri.ankara.edu.tr
}

\begin{abstract}
In this study, the effects of foliar kaolin particle film treatment (PF) on some table grape quality characteristics of cv. Trakya Ilkeren grown in Ankara conditions were investigated. The application of kaolin particle film (3\%) was started just after fruit set. Treatments were repeated weekly for three weeks. Yield per vine was found to be $3.60 \mathrm{~kg}$ in Control (C) and $3.93 \mathrm{~kg}$ in PF treatment. No significant effect of PF treatment on grape yield was determined. TSS and maturity index were affected positively by PF treatment. TSS was determined as $19.45^{\circ} \mathrm{Bx}$ and $20.68^{\circ} \mathrm{Bx}$ in $\mathrm{C}$ and $\mathrm{PF}$ treatment respectively. The maturity index (\%) increased from 30.30 (C) to 35.28 (PF) due to the increase in TSS. No differences in $\mathrm{pH}$ and titratable acidity were observed between $\mathrm{PF}$ and $\mathrm{C}$. While cluster weight increased from $314.48 \mathrm{~g}(\mathrm{C})$ to $357.47 \mathrm{~g}(\mathrm{PF})$, cluster length increased from $17.14 \mathrm{~cm}(\mathrm{C})$ to $19.02 \mathrm{~cm}(\mathrm{PF})$. No significant change in cluster width, berry weight, width, length and berry firmness were determined. More intense skin color was obtained from PF treatment according to CIRG index. Considering the findings, it was concluded that PF treatment led to the development in quality attributes of cv. Trakya Ilkeren grown under high solar radiation and temperature stress.
\end{abstract}

\section{Kaolin Partikül Film Uygulamasının Trakya İlkeren ( $V$. vinifera L.) Çeşidinin Sofralık Kalite Özelliklerine Etkisi}

\section{ÖZET}

Bu çalışmada, Ankara koşullarında yetiştirilen Trakya İlkeren üzüm çeşidinde kaolin partikül film (PF) uygulamasının sofralık kalite özellikleri üzerindeki etkisi incelenmiştir. Tane tutumundan başlayarak haftada birer kez olmak üzere yaprak yüzeyine (\%3) toplam 3 uygulama yapılmıştır. Sofralık özellikler kapsamında omca verimi, olgunluk ölçütleri (SÇKM, pH, titrasyon asitliği, olgunluk indisi), salkım ve tane özellikleri ile tane kabuk rengi değerlendirilmiştir. PF uygulaması omca veriminde istatistik düzeyde önemli bir etki belirlenmemiştir. Omca verimi kontrol (K) grubunda $3.60 \mathrm{~kg}$, PF uygulamasında ise $3.93 \mathrm{~kg}$ olarak belirlenmiştir. Olgunluk ölçütlerinden SÇKM ve olgunluk indisi PF uygulamasından olumlu etkilenmiştir. SÇKM Kontrol grubunda $19.45{ }^{\circ} \mathrm{Bx}$, PF uygulamasında $20.68{ }^{\circ} \mathrm{Bx}$ olarak belirlenmiştir. SÇKM artışına bağlı olarak olgunluk indisi (\%) 30.30'dan (K) 35.28'e (PF) yükselmiştir. $\mathrm{pH}$ ve asitlik düzeylerinde önemli bir etki belirlenmemiştir. Salkım boyu ve ağırlığında önemli artışlar sağlanmış, salkım boyu $17.14 \mathrm{~cm}$ 'den (K) 19.02 cm'ye (PF) yükselirken, salkım ağırlığı 314.48 g'dan (K) 357.47 g'a (PF) yükselmiştir. Tane ağırlığı, eni, boyu ve sertliğinde önemli değişim belirlenmemiştir. CIRG indeksine göre, PF uygulaması tane kabuğunda renk yoğunluğunun artışına da katkı sağlamıştır. Sonuç olarak, partikül film uygulamasının yoğun güneşlenme ve yüksek sıcaklık koşullarında yetiştirilen Trakya İlkeren çeşidinde sofralık özelliklerin geliştirilmesine katkı sağladığı sonucuna ulaşılmıştır.

\section{Research Article}

$\begin{array}{ll}\text { Article History } \\ \text { Received } & : 29.05 .2020 \\ \text { Accepted } & : 22.09 .2020\end{array}$

Keywords
Particle film
Stress mitigation
Table grape
Quality
Yield

\section{Araştırma Makalesi}

Makale Tarihçesi

Geliş Tarihi : 29.05 .2020

Kabul Tarihi : 22.09 .2020

\section{Anahtar Kelimeler}

Partikül film

Stres önleyici

Sofralık üzüm

Kalite

Verim 
To Cite : Cantürk S, Kunter B 2021. Effects of Kaolin Particle Film Treatment on Table Grape Characteristics of cv. Trakya Ilkeren (V. vinifera L.). KSU J. Agric Nat 24 (3): 522-528. https://doi.org/10.18016/ksutarimdoga.vi.745100.

\section{INTRODUCTION}

The composition of the grape berries is known to be quite sensitive to macro and micro environmental factors (Kuhn et al. 2014). The ecologic conditions have a high impact on growth, yield and synthesis and accumulation of primary and secondary metabolites in grape berry (Teixeira et al. 2013). Especially sunlight exposure and temperature are regarded as the main factors on grape berry composition and metabolism since many of the biological pathways are largely depend on light and temperature (Spayd et al. 2002; Gökçen et al. 2017). In terms of viticulture, continental climatic conditions provide a quite hot and dry vegetation period that has limited rainfall, hightemperature differences between day and night. In such ecologies, intense solar radiation and hightemperature conditions prevent carbon assimilation by increasing the temperature in the canopy and triggers the deterioration of the balance between vegetative and reproductive development. As a result, yield and quality are limited in the grapevine under stress conditions (Wahid et al. 2007; Shellie and King 2013). In central Anatolia, excessive summer temperatures affect the vineyards mainly from early June to September. Therefore, planning and practicing stressreducing strategies have great importance to achieve expected yield and quality.

In this context, the application of foliar-applied and clay-based reflective compounds for reducing stress effects on fruit species has become widespread. It has been reported that these reflective materials have positive effects on physiology, productivity and fruit quality against abiotic stress in many plant species (Glenn et al. 1999; Yazıcı and Goksu 2017; Khaleghi et al. 2015). The use of stress-reducing materials like kaolin in viticulture has not been attracted much attention due to the adaptation ability of grapevine to dry conditions. However, higher temperatures and summer droughts as a result of climate change negatively affect the vineyards, and stress mitigation strategies gain importance in recent years (Conde et al. 2016). A number of studies were conducted about the effects of kaolin particle films on grape cultivars and promising results have been reported in terms of berry composition and wine quality (Song et al. 2012; Shellie and King 2013; Coniberti et al. 2013; Lobos et al. 2015; Canturk et al. 2018 and 2019). In contrast to wine grapes, the effects of particle film on quality attributes peculiar to table grapes like berry and cluster characteristics have not yet been investigated adequately. The cultivar Trakya Ilkeren is preferred by the grape growers of Central Anatolia due it is well suited for fresh consumption. Also, under limited irrigation conditions and relatively short vegetation period of this area, it has an advantage of very early ripening. In order to minimize the potential damage of water stress and solar radiation, it is important to complement the viticultural knowledge about how particle film affects table grapes. Therefore, in this study, it is aimed to investigate the effects of kaolin foliar particle film treatment $(\mathrm{PF})$ on yield and ripeness parameters as well as cluster and berry properties in cv. Trakya Ilkeren ( V.vinifera L.) grown under high solar radiation and temperature stress.

\section{MATERIAL and METHODS}

\section{Plant Material}

The experiment was conducted in the vineyards of Research Station for Viticulture in Kalecik, Ankara $\left(40^{\circ} 06^{\prime} \mathrm{N} 33^{\circ} 25^{\prime} \mathrm{E}, 670 \mathrm{~m}\right.$ a.s.l.) during the growing season of 2018 - 2019. The thirteen years old vines of cv. Trakya Ilkeren (Vitis vinifera L.) (released from the national breeding program, crossing combination: Alphonse Lavallée $\times$ Perlette) were used in the study. The cultivar is used for fresh consumption thanks to its large berries and attractive black skin color. The vines were trained to bilateral cordon and spur pruned from 2 buds. They were grafted onto 1103P rootstock with $1.5 \times 3 \mathrm{~m}$ row spacing. The experimental vineyard soil was clay loam with a $\mathrm{pH}$ of 7.5 . The research region has a continental climate. The main climatic conditions in 2018 and 2019 vegetation were given in Table 1. Meteorological data were obtained from the climatic station of Turkish State Meteorological Service located in the research area.

\section{Kaolin Particle Film (PF) Treatment}

Kaolin based particle film (Screenduo, CMM Inc.) treatment was started just after the berry set. The experiment was planned as three replicates each consisting of 3 vines. Randomly selected vines were homogenously sprayed in the early morning period from 08.00-10.00 a.m. with a backpack sprayer. The product was only applied to the leaves weekly for three weeks at a rate of $3 \%(\mathrm{w} / \mathrm{v})$. The plot was divided into two blocks, one for PF treatment and one for Control vines. Untreated vines were left as the Control (C). All grapevines were limitedly irrigated once in July and August. All the grapes were hand-harvested at approximately $17-18^{\circ} \mathrm{Bx}$ on August 17, 2018 and August 23, 2019.

\section{Yield and Ripeness Parameters}

Yield per vine $(\mathrm{kg})$ was determined by weighing the clusters of each vine during the harvest. For measuring ripeness parameters, right after the harvest 100 berries were randomly selected from PF treated and $\mathrm{C}$ vines. Then the berries were manually 
crushed, filtered and analyses were carried out in must. Soluble solid content (TSS) was measured using an Atago Master-M refractometer. Mettler Toledo DL50 (Graphics) automatic titrator was used for measure titratable acidity (TA) and $\mathrm{pH}$ values.
Titratable acidity was measured with $0.1 \mathrm{~N} \mathrm{NaOH}$ and expressed as $\mathrm{gL}^{-1}$ tartaric acid equivalents. Maturity index (MI) of the berries was also calculated.

Table 1. Climatic conditions of research vineyard (Kalecik-Ankara) in 2018-2019 vegetation Cizelge 1. Araştırma alanının (Kalecik-Ankara) 2018-2019 vejetasyon dönemine ait iklim koşulları

\begin{tabular}{|c|c|c|c|c|c|c|c|c|}
\hline \multirow[t]{2}{*}{$\begin{array}{l}\text { Months (Aylar)/ } \\
\text { Years (Yillar) }\end{array}$} & \multicolumn{2}{|c|}{$\begin{array}{l}\text { Minimum air } \\
\text { temperature }\left({ }^{\circ} \mathrm{C}\right) \\
(\text { En düşük sıcaklık })\left({ }^{\circ} \mathrm{C}\right)\end{array}$} & \multicolumn{2}{|c|}{$\begin{array}{l}\text { Maximum air } \\
\text { temperature }\left({ }^{\circ} \mathrm{C}\right) \\
\left(\text { En yüksek sicaklık) }\left({ }^{\circ} \mathrm{C}\right)\right.\end{array}$} & \multicolumn{2}{|c|}{$\begin{array}{l}\text { Mean air temperature } \\
\left({ }^{\circ} \mathrm{C}\right) \\
(\text { Ortalama sicaklık })\left({ }^{\circ} \mathrm{C}\right)\end{array}$} & \multicolumn{2}{|c|}{ 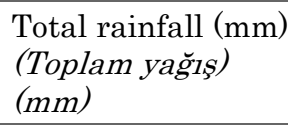 } \\
\hline & 2018 & 2019 & 2018 & 2019 & 2018 & 2019 & 2018 & 2019 \\
\hline March (Mart) & -4.1 & -3.9 & 24.2 & 22.1 & 10.8 & 7.4 & 43.7 & 28.5 \\
\hline April (Nisan) & -0.8 & -1.3 & 28.6 & 27.3 & 14.9 & 11.1 & 8.2 & 30.4 \\
\hline May (Mayıs) & 6.9 & 3.5 & 31.1 & 35.9 & 18.3 & 18.1 & 174 & 37.0 \\
\hline June (Haziran) & 11.1 & 12.8 & 36.1 & 34.3 & 22.4 & 22.7 & 70.5 & 145.2 \\
\hline July (Temmuz) & 14.6 & 9.6 & 37.2 & 37.2 & 25.5 & 22.9 & 13.5 & 12.2 \\
\hline August (Ă̈ustos) & 12.7 & 11.2 & 38.3 & 37.9 & 25.5 & 24.0 & 5.5 & 33.3 \\
\hline September (Eylül) & 6.9 & 2.8 & 35.9 & 32.7 & 20.8 & 19.7 & 3.0 & 0.4 \\
\hline
\end{tabular}

\section{Cluster and Berry Characteristics}

The weight of clusters was determined by a digital scale. Cluster length $(\mathrm{cm})$ and cluster width $(\mathrm{cm})$ were measured with ruler and cluster compactness was assessed according to OIV 204 (Anonymous, 2011). For berry measurements, 100 berries were randomly selected. Berry weight was determined by the average of weighing 100 berries using a digital scale. The measurements of berry width $(\mathrm{mm})$ and length $(\mathrm{mm})$ were done using a digital caliper. Berry firmness was evaluated using a penetrometer (Effegi FT02) with a $3.0 \mathrm{~mm}$ probe. Measurements were done on the equatorial section of the berries $(\mathrm{N})$. Berry skin color measurements were made on the equatorial position of the berries. Parameters of $\mathrm{L}^{*}, \mathrm{a}^{*}$ and $\mathrm{b}^{*}$ were determined by a Konica Minolta CR200 chroma meter. Then, hue angle and chroma values were calculated and converted to CIRG index according to Carreño et al. (1996).

\section{Statistical Analysis}

Descriptive statistics for the studied characteristics were presented as the mean and their standard errors. For each characteristic, ANOVA (Analysis of Variance) was used to compare Control and PF group means. Because of no statistical difference was detected between 2018 and 2019 data, the means of both years were presented. Statistical significance level was considered as 5\% and SPSS (ver: 21) statistical program was used for all statistical computations.

\section{RESULTS and DISCUSSION}

Effects of PF Treatment on Yield, Cluster and Berry Size

The effect of PF treatment on the quality characteristics of Trakya Ilkeren was presented in Table 2, 3 and 4. Although the effect of PF treatment on the yield was not statistically significant, there was a numerical increase in yield. Yield per vine was determined as $3.93 \mathrm{~kg}(\mathrm{PF})$ and $3.60 \mathrm{~kg}(\mathrm{C})$ (Table 2). Many studies on grapevines demonstrated that foliar particle film treatment has not remarkable effect on grape yield (Cooley et al. 2008; Shellie and Glenn, 2008; Glenn et al. 2010; Brillante et al. 2016; Korkutal et al. 2019 and 2020). However, in the studies conducted in some other species, yield increase was obtained, and authors attributed this to the favorable effect of kaolin on sunburn and heat stress damages (Glenn et al. 2001; Cantore et al. 2009). Same as the previous results on grapevine, there was a limited increase in yield in this study, which was regarded as a positive result.

$\mathrm{PF}$ treatment led to a significant increase in cluster weight. $357.47 \mathrm{~g}$ and $314.48 \mathrm{~g}$ cluster weight were obtained in PF treatment and C, respectively (Table 2). Similarly, an important increase in cluster size was achieved. Cluster length increased from $17.14 \mathrm{~cm}$ (C) to $19.02 \mathrm{~cm}(\mathrm{PF})$. The increase in cluster width was not statistically significant. The findings were determined as $15.61 \mathrm{~cm}(\mathrm{PF})$ and $14.09 \mathrm{~cm}(\mathrm{C})$. A considerable effect of PF treatment on cluster compactness could not be determined. The compactness of all the clusters was evaluated visually as " 5 -middle" class according to OIV 204 (Fig 1). PF treatment had favorable effects on berry weight, berry width, and length, but the increases did not make a statistical difference (Table 2). The berry weight was determined as $3.96 \mathrm{~g}$ in $\mathrm{C}$, it increased to $4.34 \mathrm{~g}$ in PF treatment. Berry width measurements ranged from $18.63(\mathrm{PF})$ to $17.92 \mathrm{~mm}$ (C), while berry length findings were determined as $17.87(\mathrm{PF})-17.40 \mathrm{~mm}$ (C). Measurements of berry firmness were also similar between $\mathrm{PF}$ treatment and C. The findings were $4.34(\mathrm{PF})$ and $3.96 \mathrm{~N}$ (C). In previous studies, it was seen that $\mathrm{PF}$ treatment affects cluster and berry characteristics in different ways. 
Shellie and Glenn (2008) stated that particle film treatment does not affect the cluster weight of Viognier and Merlot. In terms of berry weight, there was no significant effect on Viognier, while there was an increase in Merlot. Some other studies indicated that no significant effect was determined in cluster and berry size in the vines treated with particle film
(Shellie and King 2013; Brillante et al. 2016; Canturk et al. 2019). Assessing of the relation between the cluster and berry size, the favorable effect of PF treatment on cluster size was not attributed to the increase in berry size. It was concluded that the positive effects of $\mathrm{PF}$ treatment were provided on yield, cluster weight and length.

Table 2. Effects of PF treatment on yield, cluster and berry size of cv. Trakya Ilkeren

Çizelge 2. PF uygulamasının Trakya İlkeren çeşidinde verim, salkım ve tane özelliklerine etkisi

\begin{tabular}{|c|c|c|c|}
\hline & $\mathrm{PF}$ & $\mathrm{C}$ & $\begin{array}{l}\text { Significance } \\
\text { (Önem düzeyi) }\end{array}$ \\
\hline Yield per vine $(\mathrm{kg})($ Verim) $(\mathrm{kg})$ & $3.93 \pm 0.23$ & $3.60 \pm 0.26$ & NS \\
\hline \multicolumn{4}{|l|}{ Cluster size (Salkım büyüklüğü) } \\
\hline Cluster weight (g) (Salkım ăğrlı̆ğ $)(g)$ & $357.47 \pm 17.20$ & $314.48 \pm 8.22$ & * \\
\hline Cluster width $(\mathrm{cm})$ (Salkım eni) (cm) & $15.61 \pm 0.44$ & $14.09 \pm 0.27$ & NS \\
\hline Cluster length $(\mathrm{cm})($ Salkım boyu) $(\mathrm{cm})$ & $19.02 \pm 0.45$ & $17.14 \pm 0.22$ & * \\
\hline \multicolumn{4}{|l|}{ Berry size (Tane büyüklüğü) } \\
\hline Berry weight (g) (Tane ăğgrliğg) (g) & $4.34 \pm 0.16$ & $3.96 \pm 0.11$ & NS \\
\hline Berry width (mm) (Tane eni) (mm) & $18.63 \pm 0.32$ & $17.92 \pm 0.27$ & $\mathrm{NS}$ \\
\hline Berry length (mm) (Tane boyu) ( $\mathrm{mm}$ ) & $17.87 \pm 0.31$ & $17.40 \pm 0.25$ & $\mathrm{NS}$ \\
\hline Berry firmness (N) (Tane sertliği) (N) & $4.34 \pm 0.16$ & $3.96 \pm 0.11$ & NS \\
\hline
\end{tabular}

In each line, * represents statistically significant differences among the $\mathrm{PF}$ and $\mathrm{C}(p \leq 0.05)$.

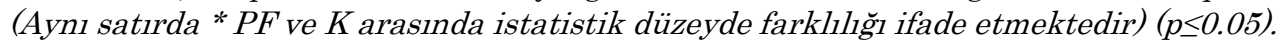

NS: Not significant (Önemli değgil)

PF: Particle film treatment (Partikül Film Uygulaması), C: Control (Kontrol-K)

Effects of PF Treatment on Berry Skin Color and Ripeness Parameters

The definition of berry skin color was made according to CIRG index. Numerical values obtained from the Minolta CR200 chroma meter were 4.13 in PF treatment and 3.74 in $\mathrm{C}$ (Table 3). According to the measurements, the berry skin color was defined as "red-violet" in PF treated vines and "red" in C. It was seen that the treatment caused to increase in the skin color intensity by increasing CIRG value. It was reported that total anthocyanin content and the proportional distribution between the anthocyanin components were directly affect the formation of berry skin color in grapes. CIRG index was regarded as the reflection of anthocyanin content to skin color (Carreño et al. 1996). Although the anthocyanin content was not included in this study, the increases in CIRG values could be interpreted that $\mathrm{PF}$ treatment increased the anthocyanin accumulation in Trakya Ilkeren. It was also reported that PF treatment has favorable effects on anthocyanin and phenol biosynthesis under excessive solar radiation and high-temperature conditions, which was due to reduced canopy temperature. In one of these studies, Kök and Bal (2017) reported that combination of leaf removal and kaolin particle film increased total anthocyanin and total phenol content in Muscat of Hamburg. Song et al. (2012) also indicated that particle film treatment increased total anthocyanin content of Merlot cultivar under different irrigation regimes. Brillante et al. (2016) found that kaolin particle film treatment increased anthocyanin content by $35 \%$ compared to Control in Cabernet Sauvignon. In Beauty Seedless and Tekirdag Seedless, particle film treatment contributed increasing total anthocyanin content and CIRG index (Canturk et al. 2019). In accordance with the previous studies, present study revealed that $\mathrm{PF}$ treatment improved the berry skin color significantly.

Table 3. Effects of PF treatment on skin color of cv. Trakya Ilkeren

Cizelge 3. PF uygulamasının Trakya Ilkeren çeşidinde tane kabuk rengine etkisi

\begin{tabular}{lll}
\hline Skin color characteristics (Tane kabuk rengi özellikleri) & $\mathrm{PF}$ & $\mathrm{C}$ \\
\hline CIRG (CIRG) & $4.13 \pm 0.09^{*}$ & $3.74 \pm 0.04$ \\
\hline Color definition (Renk tanımlaması) & Red-violet (Kırmızı-menekşe) & Red (Kırmızı)
\end{tabular}

In the line, * represents statistically significant difference among the $\mathrm{PF}$ and $\mathrm{C}(p \leq 0.05)$.

(Aynı satırda *PF ve K arasında istatistik düzeyde farklılı̆̆ ifade etmektedir) ( $\leq \leq 0.05$ ).

PF: Particle film treatment (Partikül Film Uygulaması)

C: Control (Kontrol-K) 


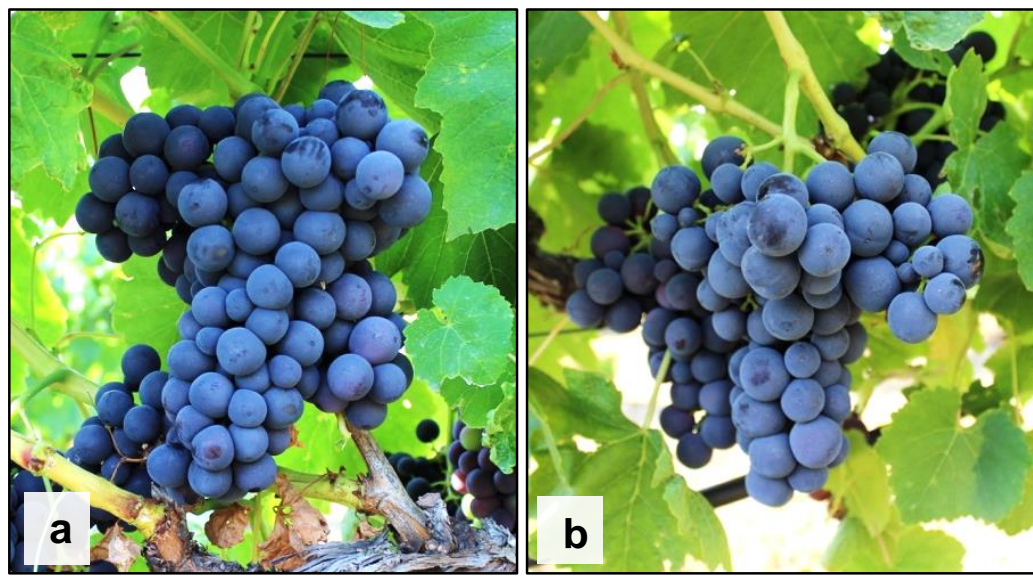

Figure 1. Clusters that skin color was defined as "red-violet" in PF treatment (a) and "red" in Control (b) according to CIRG index.

SSekil 1. Tane kabuk rengi "kırmızı-menekşe" olarak tanımlanan PF uygulanmıs salkımlar (a) ve "kırmızı" olarak tanımlanan Kontrol grubu (b) salkımlar

The effect of PF treatment on ripeness parameters was given in Table 4. PF treated vines showed a significantly higher TSS compared to $\mathrm{C}$ vines. TSS values of the clusters harvested on the same day were $20.68{ }^{\circ} \mathrm{Bx}$ in $\mathrm{PF}$ treatment and $19.45{ }^{\circ} \mathrm{Bx}$ in $\mathrm{C}$ vines. Titratable acidity was found to be $5.89 \mathrm{gL}^{-1}$ in $\mathrm{PF}$ treatment and $6.43 \mathrm{gL}^{-1}$ in $\mathrm{C}$. There has been a little decrease in acidity compared to $\mathrm{C}$ vines, but this value was not a significant level statistically. Likewise, no difference was detected in $\mathrm{pH}$ values. The maturity index increased significantly in PF treated grapevines due to the increase in TSS. While the maturity index was $30.30 \%$ in $\mathrm{C}$, it increased to $35.28 \%$ in $\mathrm{PF}$ treatment. Similar results have been obtained in many of the previous studies. Song et al. (2012) stated that particle film treatment in Merlot did not make a statistical difference on the TSS, $\mathrm{pH}$, titratable acidity and maturity index at different irrigation levels. The results of Coniberti et al. (2013) also indicated that ripeness parameters of Sauvignon Blanc did not change in the combination of leaf removal and particle film treatment. However, in Muscat of Hamburg, particle film and leaf removal combination increased the TSS, but it did not affect titratable acidity (Kök and Bal 2017).

Table 4. Effects of PF treatment on ripeness parameters of cv. Trakya Ilkeren Cizelge 4. PF uygulamasının Trakya İlkeren çeşidinde olgunluk parametrelerine etkisi

\begin{tabular}{llll}
\hline $\begin{array}{l}\text { Ripeness parameters } \\
\text { (Olgunluk parametreleri) }\end{array}$ & $\mathrm{PF}$ & $\mathrm{C}$ & $\begin{array}{l}\text { Significance } \\
\text { (Önem düzeyi) }\end{array}$ \\
\hline TSS $\left({ }^{\circ} \mathrm{Bx}\right)\left(S C K M\left({ }^{\circ} \mathrm{Bx}\right)\right)$ & $20.68 \pm 0.46^{\mathrm{a}}$ & $19.45 \pm 0.27^{\mathrm{b}}$ & $*$ \\
\hline $\mathrm{pH}(\mathrm{pH})$ & $3.28 \pm 0.03$ & $3.22 \pm 0.06$ & $\mathrm{NS}$ \\
\hline Titratable acidity $\left(\mathrm{gL}^{-1}\right)$ (Titrasyon asitliği $\left.\left(g L^{-1}\right)\right)$ & $5.89 \pm 0.02$ & $6.43 \pm 0.03$ & $\mathrm{NS}$ \\
\hline Maturity index $(\%)($ Olgunluk indisi $(\%))$ & $35.28 \pm 1.10^{\mathrm{a}}$ & $30.30 \pm 0.81^{\mathrm{b}}$ & $*$ \\
\hline
\end{tabular}

In each line, * represents statistically significant differences among the $\mathrm{PF}$ and $\mathrm{C}(p \leq 0.05)$.

(Aynı satırda *PF ve K arasında istatistik düzeyde farkllllı̆ ifade etmektedir) ( $\leq \leq 0.05)$.

NS: Not significant (Önemli değgil)

PF: Particle film treatment (Partikül Film Uygulaması)

C: Control (Kontrol-K)

\section{CONCLUSION}

In this study, it was determined that kaolin particle film treatment in cv. Trakya Ilkeren had positive effects on the cluster size and berry skin color intensity. The increase in cluster weight and length was considered as an important result in terms of improving physical characteristics of cv. Trakya Ilkeren that early ripening table grape cultivar growing in the hot and dry region. An improvement was achieved in berry skin color intensity, which was a factor that increases the value of fresh consumption.
This improvement was a result of the regulated anthocyanin biosynthesis via PF treatment that was mentioned in previous studies (Brillante et al. 2016; Canturk et al. 2019). However, the effects of PF treatment on yield and the physical measurements of berries were found to be limited. Increasing the total soluble solid, which is an important maturity parameter, was evaluated as a noticeable result. Considering the findings obtained in the study, it was concluded that particle film treatment contributed to the improvement of table grape characteristics in cv. Trakya Ilkeren grown in hot and dry conditions. 


\section{ACKNOWLEDGEMENTS}

We sincerely acknowledge Ankara University Faculty of Agriculture for conducting this research on the vineyards of the Research Station for Viticulture and MSc. Agricultural Engineer Hayati ÇETINER for his professional and technical support.

\section{Author's Contributions}

The contribution of the authors is equal.

\section{Statement of Conflict of Interest}

Authors have declared no conflict of interest.

\section{REFERENCES}

Anonymous 2011. OIV Descriptor List for Grape Varieties and Vitis Species (2nd edition) (Available online with updates at http://www.oiv.int/ public/medias/2274/code-2e-edition-finale.pdf).

Brillante L, Belfiore N, Gaiotti F, Lovat L, Sansone L, Poni S, Tomasi D 2016. Comparing Kaolin and Pinolene to Improve Sustainable Grapevine Production During Drought. Plos One, 11(6): e0156631.

Cantore V, Pace B, Albrizio R 2009. Kaolin-based Particle Film Technology Affects Tomato Physiology, Yield and Quality. Environ. Exp. Bot., 66: 279-288.

Canturk S, Kunter B, Coksari G 2018. Effects of Kaolin and Dicarboxylic Acid Based Stress Inhibitors on Aroma Composition of Two Table Grape Cultivars (V.vinifera L.). Acta Sci. Pol. Hortorum Cultus, 17(5):37-46.

Canturk S, Kunter B, Buyukkartal N 2019. Effects of Kaolin Particle Film on Berry Histological Properties in Two Table Grape Cultivars ( $V$. vinifera L.).Journal of Berry Research,9(2):309-319.

Carreño J, Martínez A, Fernández-López JA 1996. Measuring the Color of Table Grapes. Color Research \& Application, 21(1): 50-54.

Conde A, Pimentel D, Neves A, Dinis LT, Bernardo S, Correia CM, Gerós H, Pereira JM 2016. Kaolin Foliar Application Has a Stimulatory Effect on Phenylpropanoid and Flavonoid Pathways in Grape Berries. Front. Plant Sci., 7(1150):1-14.

Coniberti A, Ferrari V, Dellacassa E, Boido E, Carrau F, Gepp V, Disegna E 2013. Kaolin Over Sunexposed Fruit Affects Berry Temperature, Must Composition and Wine Sensory Attributes of Sauvignon Blanc. Europ. J. Agronomy, 50:75-81.

Cooley NM, Glenn DM, Clingeleffer PR, Walker RR 2008. The Effects of Water Deficit and Particle Film Technology Interactions on Cabernet Sauvignon Grape Composition. Proc. VthIS on Irrigation of Hort Crops Acta Hort., 792, ISHS193-200.

Glenn DM, Puterka GJ, van der Zwet T, Byers RE, Feldhake C 1999. Hydrophobic Particle Films: A New Paradigm for Suppression of Arthropod Pests and Plant Diseases. J. Econ. Entomol., 92:759-771. Glenn DM, Puterka GJ, Drake SR, Unruh TR, Knight AL, Baherle P, Prado E, Baugher TA 2001. Particle Film Application Influences Apple Leaf Physiology, Fruit Yield, and Fruit Quality J. Amer. Soc. Hort. Sci., 126(2):175-181.

Glenn DM, Cooley N, Walker R, Clingeleffer P, Shellie K 2010. Impact of Kaolin Particle Film and Water Deficit on Wine Grape Water Use Efficiency and Plant Water Relations. HortScience, 45(8):11781187.

Gökçen İS, Keskin N, Kunter B, Cantürk S, Karadoğan B 2017. Grape Phytochemicals and Researches on Grape Cultivars Grown in Turkey. Turkish Journal of Forest Science, (Tr. and Ing Abst.), 1(1): 93-111.

Khaleghi E, Arzani K, Moallemi N, Barzegar M 2015. The Efficacy of Kaolin Particle Film on Oil Quality Indices of Olive Trees (Olea europaea L.) cv 'Zard' Grown Under Warm and Semi-arid Region of Iran. Food Chem., 166:35-41.

Korkutal İ, Bahar E, Güvemli-Dündar, D 2019. Ben Düşme Dönemi ve Sonrasinda Uygulanan Antitranspirantların Cabernet Sauvignon Üzüm Çeşidinde Şıra Özellikleri ve Verime Etkileri. Akademik Ziraat Dergisi 8(2):173-184.

Korkutal İ, Bahar E, Güvemli-Dündar D 2020. Ben Düşme Bönemi ve Sonrası Antitranspirant Uygulamalarının Tane ve Salkım Özellikleri Üzerine Etkilerinin Belirlenmesi Ege Üniv. Ziraat Fak. Derg., 57(1):83-93.

Kök D, Bal E 2017. Leaf Removal Treatments Combined with Kaolin Particle Film Technique from Different Directions of Grapevine's Canopy Affect the Composition of Phytochemicals of cv. Muscat of Hamburg ( $V$. vinifera L.). ErwerbsObstbau, 1-7.

Kuhn N, Guan L, Dai ZW, Wu B, Lauvergeat V, Gomès E, Li SH, Godoy F, Arce-Johnson P, Delrot S 2014. Berry Ripening: Recently Heard Through the Grapevine-Review Paper. J. Exp. Bot., 65(16):45434559.

Lobos GA, Acevedo-Opazo C, Guajardo-Moreno A, Valdés-Gómez H, Taylor JA, Laurie VF 2015. Effects of Kaolin-based Particle Film and Fruit Zone Netting on Cabernet-Sauvignon Grapevine Physiology and Fruit Quality. J. Int. Sci. Vigne Vin., 49:137-144.

Shellie K, Glenn DM 2008. Wine Grape Response to Kaolin Particle Film Under Deficit and Wellwatered Conditions. Proc. $V^{\text {th }}$ IS on Irrigation of Hort. Crops, Acta. Hort., 792, ISHS 587-592.

Shellie K, King BA 2013. Kaolin Particle Film and Water Deficit Influence Malbec Leaf and Berry Temperature, Pigments, and Photosynthesis. Amer. J. Enol. Vitic., 64(2):223-230.

Song J, Shellie KC, Wanga H, Qian MC 2012. Influence of Deficit Irrigation and Kaolin Particle Film on Grape Composition and Volatile Compounds in 
Merlot Grape (Vitis vinifera L.). Food Chem., 134:841-850.

Spayd SE, Tarara JM, Mee DL, Ferguson JC 2002. Separation of Sunlight and Temperature Effects on the Composition of Vitis vinifera cv. Merlot Berries. Amer. J. Enol. Vitic., 53(3):171-182.

Teixeira A, Eiras-Dias J, Castellarin SD, Gerós H 2013. Berry Phenolics of Grapevine Under
Challenging Environments - Review. Int. J. Mol. Sci., 14:18711- 18739.

Wahid A, Gelani S, Ashraf M, Foolad MR 2007. Heat Tolerance in Plants: An Overview. Environmental and Experimental Botany, 61:199-223.

Yazıcı K, Goksu B 2017. Effects of Kaolin (M-99-099) Application on Antioxidant and Phenolic Compounds in Tea Leaves (Camellia sinensis L.O. Kuntze). Biochem. Genet., 55:367-377. 